Carbohydrate Polymers

June 2015, Volume 124, Pages 347-356

http://dx.doi.org/10.1016/j.carbpol.2015.02.038

http://archimer.ifremer.fr/doc/00254/36494/

(c) 2015 Elsevier Ltd. All rights reserved.

\title{
The marine bacteria Cobetia marina DSMZ 4741 synthesizes an unexpected $\mathrm{K}$-antigen-like exopolysaccharide
}

\author{
Lelchat Florian ${ }^{1,{ }^{*}}$, Cerantola Stéphane ${ }^{2}$, Brandily Christophe ${ }^{1}$, Colliec-Jouault Sylvia ${ }^{1}$, Baudoux \\ Anne-Claire ${ }^{3,4}$, Ojima Takao ${ }^{5}$, Boisset Claire ${ }^{6}$
}

${ }^{1}$ Laboratoire BMM, centre Ifremer de Brest, ZI pointe du diable, 29280 Plouzané, France

${ }^{2}$ Service commun de résonnance magnétique nucléaire, Faculté de science de Brest, Université de Bretagne Occidentale, 6 av. Victor Le Gorgeu, 29238 Brest Cedex 3, France

${ }^{3}$ Sorbonne Universités, UPMC Paris 06, Station Biologique de Roscoff, UMR 7144, Place George Tessier, 29680 Roscoff, France

${ }^{4}$ CNRS, station biologique de Roscoff, UMR 7144, Place George Tessier, 29680 Roscoff, France

${ }^{5}$ Laboratory of Marine Biotechnology and Microbiology, Graduate School of Fisheries Sciences, Hokkaido University, Minato-cho 3-1-1, Hakodate 041-8611, Japan

${ }^{6}$ Service commun de chromatographie, CERMAV-CNRS, 601 rue de la chimie, St Martin d'Hère, 38041 Grenoble, France

* Corresponding author : Florian Lelchat, Tel.: +33 625670668 ;

email address : florian.lelchat@gmail.com

\begin{abstract}
:
We have studied the exopolysaccharide produced by Cobetia marina DSMZ 4741, a marine bacterium isolated from coastal seawater. This strain is able to produce a polysaccharide in presence of carbon sources as glucose, mannitol and alginate. The maximum production occurs in aerobic condition, during the end of the exponential phase. The polymer is a non-viscous, acidic heteropolysaccharide of 270 $\mathrm{kDa}$ constituted of a repeating unit of:

$\rightarrow 2)-\beta-D-R i b f-(1 \rightarrow 4)-[7,8-O-(P y r)]-\alpha-D-K D O p-(2 \rightarrow$

This kind of chemical structure is generally related to K-antigen polysaccharide of pathogenic Escherichia coli strains. This is the first time this type of EPS is described from a marine bacterium. Moreover the polysaccharide exhibits a pyruvate substitution on its 3-deoxy-D-manno-oct-2-ulosonic acid (KDO) residue never encountered before. The discovery of such an unexpected EPS with high biotechnological potential is a new incentive for a better exploration of bioactive marine resources.
\end{abstract}




\section{Highlights}

- The marine bacteria Cobetia marina DSMZ 17117 synthesize an exopolysaccharide (named L6); The repetitive unit of the L6 exopolysaccharide is a disaccharide constituted of ribose and pyruvated KDO; This type of structure is generally encountered in antigen-K of uropathogenic E. coli strains.

Keywords : bacterial exopolysaccharides, K-antigen, Cobetia marina, KDO, marine polysaccharide

\section{Introduction}

Exopolysaccharides (EPSs) are polymers of sugars whose synthesis has been identified in the three domains of life (Eukarya, Prokarya and Archeae) (Sutherland, 2001). Bacterial EPSs display a wide range of chemical structure with homopolymeric or heteropolymeric composition, linear or branched backbones. Organic or inorganic substituents are also frequently observed on their structures (Freitas, Alves, \& Reis, 2011). EPSs occur in two different forms as a capsular polysaccharide where the polysaccharides is closely associated with the cell surface and may be covalently bound, and as a high molecular weight slime polysaccharide that can be excreted in very high amount (Sutherland, 2001) and may be loosely bound at a limited number of discrete sites of the cell (Vanhooren \& Vandamme, 1998). EPS-producing bacteria have been isolated in a wide range of ecosystems, from human digestive tracts (Hidalgo-Cantabrana et al., 2013) to the deep hydrothermal vents (Poli, Anzelmo, \& Nicolaus, 2010), but also in oil wells (Sen, 2008) or Antarctic floe (Van der Merwe et al., 2009). Since their first descriptive studies in the middle of the last century, the biological and physicochemical unique properties of these polymers make them unavoidable in the fields of biotechnology (Sutherland, 2001; Kumar et al., 2009; Freitas et al., 2011). Because of their remarkable characteristics, they can also represent a real problem through their role in biofouling phenomenon, protecting EPS-producing bacteria against biocide and antibiotherapy, or by increasing corrosion ( Stewart \& William Costerton, 2001). In nature EPS are usually found in the form of a biogel framing the bacterial biofilm. Beyond this 'architectural' function, from an ecophysiological point of view, EPS can have multiple purposes. Its defensive roles against desiccation or grazing by protozoa as well as phages predation are the most documented ( Ophir \& Gutnick, 1994). By preventing the entry of exogenous macromolecules in the biofilm, EPSs can make some pathogenic strains 1000 times more 
resistant against antibiotics (Stewart \& Costerton, 2001). Moreover, the natural chelating properties of EPS can help bacteria to enhance nutrients bioavailability and trap toxins like heavy metals (Ordax et al., 2010). Finally, their implications in intra or inter specific allelopathy are well established (Valepyn et al., 2013).

Cobetia marina (DSMZ 4741), previously described as Arthobacter marinus, Pseudomonas marina, Pseudomonas halodurans, Deleya marina, Halomonas halodurans as well as Halomonas marina (Arahal et al., 2002) was first isolated from littoral seawater in Woodshole (USA) in 1970 (Cobet et al., 1970). It is a Gram negative aerobic bacteria, slightly halophilic, (from $0.5 \%$ to $20 \%(\mathrm{w} / \mathrm{v})$ ). This bacteria is often associated with macroalgae environment (Kraiwattanapong et al., 1998 ; Ivanova et al., 2002 ; Ivanova et al., 2005). C. marina is also well known to form biofilm and was studied as biologic model in the biofouling phenomenon (Maréchal et al., 2004). Its ability to synthetize and excrete exopolysaccharides and accumulate intracellular Poly- $\beta$-hydroxyalkanoate were already described on a different strain than DSMZ 4741 (Shea et al., 1991; Kokoulin et al., 2014).

This study presents the detailed description of a new EPS (designated as $\mathrm{L}_{6}$ ) excreted by the marine bacteria Cobetia marina strain DSMZ 4741 from the production by fermentation to its fine structural elucidation. This EPS shows chemical similarities with some K-antigen from the group II.

\section{Material and method}

\subsection{EPS production}

Cobetia marina EPS production was performed in a 31 fermenter (INFORS®) containing sterilized Zobell medium composed of yeast extract $\left(1 \mathrm{~g} . \mathrm{l}^{-1}\right)$, peptone $\left(5 \mathrm{~g} . \mathrm{l}^{-1}\right)$, Tris-base $(1.5$ g. $1^{-1}$ ) and 30 g. $1^{-1}$ of glucose, diluted in $80 \%$ filtered seawater and $20 \%$ MilliQ. The pH medium was adjusted to 7.6 and maintained this value by addition of $\mathrm{H}_{2} \mathrm{SO}_{4}$ or $\mathrm{NaOH}$. The fermenter was inoculated with a $10 \%(\mathrm{v} / \mathrm{v})$ suspension of cells in exponential phase. Bacteria were grown at $25{ }^{\circ} \mathrm{C}$ until the late exponential phase to obtain a high cell density. During the stationary growth phase, the temperature was decreased to $20{ }^{\circ} \mathrm{C}$ for 48 hours in order to enhance the EPS production. The oxygenation was monitored and regulated by stirring and air flux. The consumption of glucose was monitored with the enzyplus kit (St Gobain, France). Alternative carbon source were tested to optimize EPS biosynthesis. A production was performed in batch for mannitol (2.5 1 Erlenmeyer culture, Minitron, INFORS®) and for 
102 alginic acid in fermenter (10 1, INFORS $\left.{ }^{\circledR}\right)$ and in batch (2.5 1 Erlenmeyer culture, Minitron,

103 INFORS $®)$ with the parameters used with glucose induction.

104

105

106

107

108

109

110

111

112

113

114

115

116

117

118

119

120

121

122

123

124

125

126

127

128

129

130

\subsection{EPS extraction and purification}

At the end of the fermentation, the culture medium was centrifuged $\left(1 \mathrm{~h}, 14000 \mathrm{~g}, 4{ }^{\circ} \mathrm{C}\right)$ and the supernatant was filtered with a Buchner through a $0.45 \mu \mathrm{M}$ glass filter (Whatman®). Sodium azide $\left(\mathrm{NaN}_{3}, 0.4 \mathrm{~g} . \mathrm{l}^{-1}\right.$ final concentration) was added to the filtrate to prevent bacterial regrowth. The filtered culture supernatant containing the soluble EPS was then purified by tangential ultrafiltration with a $100 \mathrm{kDa}$ cut-off cartridge (Millipore ${ }^{\circledR}$ ) against mQ water. The purified EPS was then frozen, freeze dried and stored away from light and moisture.

\subsection{EPS analysis}

Before analysis, EPS was resuspended in MilliQ water and it was centrifuged (12000 g, 10 $\min , 20^{\circ} \mathrm{C}$ ) to remove insoluble materials. The supernatant was used for further analysis.

\subsubsection{Fourier Transform Infra Red Spectroscopy}

About $20 \mathrm{mg}$ of a lyophilized sample was placed under the beam of a FT-IR spectrometer (Nicolet sI10, ThermoScientific $®$ ) in attenuated total reflectance mode (ATR, diamond/ZnSe crystal) at ambient temperature. Spectra were acquired with 16 scans and data were processed with the Omnic spectra software (thermoscientific $®)$ ).

\subsubsection{Quantification of DNA and RNA in EPS samples}

DNA and/or RNA content of the EPS was evaluated by spectrophotometry. OD of a $0.1 \%$ EPS solution (w/v) in MilliQ water measured at $260 \mathrm{~nm}$ (Hitachi U-1800®) was converted in DNA or RNA equivalent ( 1 OD unity $=50 \mu \mathrm{g} \cdot \mathrm{ml}^{-1}$ of DNA or $40 \mu \mathrm{g} \cdot \mathrm{ml}^{-1}$ for RNA).

\subsubsection{Total sugar determination}

The Dubois colorimetric method (Dubois, 1956) takes into account all types of sugars such as aldoses, ketoses and uronic acids. This assay provides a relative percentage of total sugar content expressed in ribose equivalent used for the standard curve. A $200 \mu 1$ EPS sample solution $\left(10 \mathrm{mg} \cdot \mathrm{ml}^{-1}\right)$ was treated with $200 \mu \mathrm{l}$ of a $5 \%$ phenol solution and $1 \mathrm{ml}$ of pure $\mathrm{H}_{2} \mathrm{SO}_{4}$. The mixture was cooled to room temperature for $30 \mathrm{~min}$. Absorbance at $492 \mathrm{~nm}$ of samples as well as standard sugar (10 to $100 \mu \mathrm{g} . \mathrm{ml}^{-1}$ ribose) was read by spectrophotometry (Hitachi U-1800®). 


\subsubsection{Protein concentration measurement}

132 The Bradford method (Bradford, 1976) using Coomassie blue is based on the difference in

133 color depending on its complexation with some amino acids present in proteins. $1 \mathrm{ml}$ of

134 reagent (Biorad) was added to $20 \mu \mathrm{l}$ of sample $\left(10 \mathrm{mg}^{-\mathrm{ml}^{-1}}\right)$ and incubated $5 \mathrm{~min}$ at room

135 temperature. OD of samples as well as the standard protein $\left(0\right.$ to $0.75 \mathrm{mg}^{-1} \mathrm{ml}^{-1}$ of Bovine

136 Serum Albumin (BSA)) was measured at $595 \mathrm{~nm}$ (Hitachi U-1800®).

\section{$137 \quad$ 2.3.5 Observation of degradation products}

138 Thin Layer Chromatography (TLC) of oligosaccharides was carried out by deposit $2 \mu 1$ of 139 polysaccharide solution $\left(10 \mathrm{mg}^{-\mathrm{ml}^{-1}}\right)$ hydrolyzed with trifluoroacetic acid (2\%) at the basis of

140 Silica Gel-60 TLC plates (E. Merck®, Darmstadt, Germany) and by migrating with a solvent 141 composed of 2:1:1 1-BuOH/AcOH/ $\mathrm{H}_{2} \mathrm{O}$ in a chromatography tank. Oligosaccharides and 142 monosaccharides were visualized by spraying $10 \%(\mathrm{v} / \mathrm{v}) \mathrm{H}_{2} \mathrm{SO}_{4}$ in $\mathrm{EtOH}$, and then heating at $143120{ }^{\circ} \mathrm{C}$ for $15 \mathrm{~min}$. In order to specifically detect unsaturated/deoxy sugars, thiobarbituric acid 144 (TBA) staining was performed after the periodic acid degradation (Lanning \& Cohen, 1951). 145 Namely, the plate was sprayed with a $0.02 \mathrm{M}$ sodium periodate solution and left for $15 \mathrm{~min}$ 146 for the degradation of sugars on the plate. The plate was then sprayed with an Ethylen 147 Glycol/Acetone $/ \mathrm{H}_{2} \mathrm{SO}_{4}$ solution (50:50:0.3) and dried for $10 \mathrm{~min}$. Finally, the plate was 148 sprayed with a $6 \%(\mathrm{v} / \mathrm{v})$ solution of 2-thiobarbituric acid and heated at $150{ }^{\circ} \mathrm{C}$ for $10 \mathrm{~min}$ to 149 detect malondialdehyde produced from unsaturated/deoxy sugars as bright red spots.

\section{$150 \quad$ 2.3.6 Fractionation of EPS}

151 About $300 \mathrm{mg}$ of native EPS were diluted in $30 \mathrm{ml}$ of $5 \mathrm{mM}$ ammonium acetate buffer, $\mathrm{pH} 6$.

152 The sample was applied to a Toyopearl DEAE-650M anion exchange (Tosoh, Tokyo, Japan, $15320 \times 2.2 \mathrm{~cm}$ ) chromatographic column. Elution was performed with $600 \mathrm{ml}$ of a $\mathrm{NaCl}$ linear 154 gradient from 0 to $1 \mathrm{M}$ with a collected volume of $10 \mathrm{ml}$ per fraction. For each fraction, total 155 sugar content and uronic acid content were determined with Dubois method and 156 carbazole/sulphuric acid method respectively. EPS fractions were analyzed in a Native 157 Polyacrylamide Gel electrophoresis to observe potential difference in the migration patterns. $15812 \mu \mathrm{l}$ of fractions samples were mixed with $12 \mu \mathrm{l}$ of loading buffer (25\% (v/v) glycerol, 75 $159 \mathrm{mM}$ Tris- $\mathrm{HCl}$ (pH 8.9), 1 mM EDTA) and $5 \mu 1$ of $0.02 \%$ (w/v) Bromophenol Blue Buffer. 20 $160 \mu \mathrm{l}$ of samples were loaded in wells of a precasted $7.5 \%$ acrylamide gel (Biorad®). 161 Electrophoresis was achieved at a constant current of $20 \mathrm{~mA}$, for $50 \mathrm{~min}$ in a migration buffer 
162

163

164

165

166

167

168

169

170

171

172

173

174

175

176

177

178

179

180

181

182

183

184

185

186

187

188

189

190

191

192

comprising $25 \mathrm{mM}$ Tris $\mathrm{HCl} / 192 \mathrm{mM}$ Glycine, $\mathrm{pH}$ 8.3. The native gel was then stained with Stain All (Cosmo Bio C;., ltd, Tokyo, Japan) for 30 min and destained with distilled water under the room light.

\subsubsection{EPS molecular weight determination}

The EPS samples were dissolved at a concentration of $0.5 \mathrm{~g} . \mathrm{l}^{-1}$ in water and injected on two Shodex® columns 805 and 806 placed in series (fractionation range: 805: $4.10^{5} \mathrm{Da} ; 806$ : $2,10^{7} \mathrm{Da}$ ) . Elution was made with $0.1 \mathrm{M}$ sodium nitrate $+0.2 \%$ sodium azide at a flow rate of $0.5 \mathrm{ml} \cdot \mathrm{min}^{-1}$. Detection was performed using a refractometer (Waters ${ }^{\circledR}$ ), an 18 angles light scattering detector (Wyatt $\left.{ }^{\circledR}\right)$. For the series of measurements, the $\mathrm{dn} / \mathrm{dc}$ was taken equal to $0.150 \mathrm{ml} \cdot \mathrm{g}^{-1}$.

\subsubsection{ABEE labelled monosaccharide analysis}

This method allows to link a 4-aminobenzoate ethyl ether residue (ABEE) to the anomeric hydroxyl of a monosaccharide in acidic condition. The labelled monosaccharide can be detected with UV spectrometry. $10 \mu \mathrm{l}$ of $8 \mathrm{M}$ TFA was added to $10 \mu 1$ of a $0.1 \%$ (w/v) EPS solution. Hydrolysis was carried out for $1 \mathrm{~h}$ at $100{ }^{\circ} \mathrm{C}$. After cooling down, the sample was dehydrated with a centrifugal concentrator (30 min, $500 \mathrm{~g}$ ). Once dried, $40 \mu \mathrm{l}$ of 2-propanol was added and the sample was dehydrated again. Then, $10 \mu \mathrm{l}$ of mQ water and $40 \mu \mathrm{l}$ of ABEE-labeling reagent (Cosmo Bio Co., Ltd) were added to the sample and the mixture was incubated at $80{ }^{\circ} \mathrm{C}$ for $60 \mathrm{~min}$. Dropped at room temperature, $200 \mu \mathrm{l}$ of mQ water and $200 \mu \mathrm{l}$ of chloroform were added to the mixture, which was agitated for $1 \mathrm{~min}$. After a short centrifugation, the supernatant was recovered and filtered through a $0.2 \mu \mathrm{m}$ membrane before injection. $20 \mu \mathrm{l}$ of ABEE-derivative sample was injected to an HPLC (Prominence system, Shimadzu®, Tokyo, Japan) equipped with a Honenpak® $\mathrm{C} 18$ column $(7.5 \times 0.46 \mathrm{~cm}$, special ABEE-labeling, Cosmo Bio C., Ltd). HPLC run was performed at $1 \mathrm{ml} \cdot \mathrm{min}^{-1}$ for $60 \mathrm{~min}$ at 30 ${ }^{\circ} \mathrm{C}$ with $0.2 \mathrm{M}$ sodium borate, $\mathrm{pH} 8.9$ / acetonitrile (93/7 v/v). Detection was performed with UV absorbance at $305 \mathrm{~nm}$.

\subsubsection{Alditol acetates derivatives monosaccharide analysis}

Alditol acetates derivatives of the EPS were prepared as follows: $4 \mathrm{mg}$ of EPS were mixed with $125 \mu \mathrm{l}$ of $72 \%$ of $\mathrm{H}_{2} \mathrm{SO}_{4}$ solution. The mixture was vortexed and placed for 1 hour at ambient temperature. Then, acid was diluted to $2 \mathrm{~N}$ and left for 6 hours at $110^{\circ} \mathrm{C}$. Tubes were cooled and $200 \mu \mathrm{l}$ of hydrolyzed sample was taken to perform alditol acetates derivatives. 
193 After neutralization by ammonia, $50 \mu \mathrm{g}$ of myo-inositol were added to the sample as internal

194 standard. Monosaccharides released from hydrolysis were reduced with $1 \mathrm{ml}$ of a $195 \mathrm{NaBH}_{4} / \mathrm{DMSO}$ solution for $90 \mathrm{~min}$ at $40{ }^{\circ} \mathrm{C}$. After reduction, excess of $\mathrm{NaBH}_{4}$ was 196 decomposed by $200 \mu \mathrm{l}$ of $18 \mathrm{M}$ acetic acid. Then, $200 \mu \mathrm{l}$ of 1 -methylimidazole and $2 \mathrm{ml}$ of acetic anhydride were added to the samples. After $10 \mathrm{~min}$ of acetylation at room temperature,

$1985 \mathrm{ml}$ of distilled water were added to decompose the excess of acetic anhydride. Once the 199 tubes cooled, alditol acetates were extracted by the addition of $1 \mathrm{ml}$ of dichloromethane, 200 mixture agitation and recovery of the organic phase after a short centrifugation. The organic 201 phase was filtered through a $0.2 \mu \mathrm{m}$ syringe filter. Monosaccharides were analyzed by gas 202 chromatography (Agilent $\left.{ }^{\circledR}\right)$ and injected on a SP 2380 column with nitrogen as carrier gas $203\left(1.5 \mathrm{ml} \cdot \mathrm{min}^{-1}\right)$. The temperature program was the following: by $3 \mathrm{~min}$ at $190{ }^{\circ} \mathrm{C}, 5^{\circ} \mathrm{C} \cdot \mathrm{min}^{-1}$ up 204 to $250{ }^{\circ} \mathrm{C}$.

\subsubsection{Substituents determination}

206 Organic and inorganic substituents content was determined by High Performance Anion 207 Exchange Chromatography/ Conductivity Detection (HPAEC/CD;GP 50 pump and ED 50 208 detector, Dionex ${ }^{\circledR}$ ) equipped with a AG11HC Ionpac precolumn (Dionex ${ }^{\circledR} 4 \times 50 \mathrm{~mm}$ ), a 209 AS11HC Ionpac Analytical column (4x250 mm Dionex®), a ATC-HC Ionpac-Trap ion trap 210 column (9x75 mm, Dionex $\left.{ }^{\circledR}\right)$ and a ASRS 300 suppressor (4 mm, Dionex $\left.{ }^{\circledR}\right)$. A 2 mg.ml ${ }^{-1}$ 211 EPS solution was hydrolyzed with $0.8 \mathrm{~N} \mathrm{HCl}$ for $3 \mathrm{~h}$ at $110{ }^{\circ} \mathrm{C}$. The solution was then diluted 212 with $2 \mathrm{ml}$ of $\mathrm{H}_{2} \mathrm{O}$ and $20 \mu \mathrm{l}$ were injected into the column. Elution was carried out with a $213 \mathrm{NaOH}$ linear gradient from $0.15 \mathrm{mM}$ to $6 \mathrm{mM}$. Substituents were identified by comparison 214 with a standard mixture (lactate, acetate, succinate, pyruvate, sulfate, phosphate) and 215 concentrations were calculated with reference to an internal standard (nitrate, absent from the 216 EPS).

\section{$217 \quad 2.4$ Structural elucidation of the EPS}

$218 \quad 2.4 .1$ NMR

219 About $10 \mathrm{mg}$ of native and depolymerized $\mathrm{L}_{6}$ fractions were analyzed by NMR after three 220 exchanges/dehydration cycles in deuterated water (99.9\%). EPS were resuspended in $700 \mu 1$ $221 \mathrm{D}_{2} \mathrm{O}$. 1D and 2D NMR spectra were recorded at room temperature in the Laboratory of 222 Nuclear Magnetic Resonance Spectroscopy (University of Western Brittany) on a $500 \mathrm{MHz}$ 223 Bruker® spectrometer . 


\subsubsection{Glycosidic linkage analysis}

Glycosyl-linkage positions were determined with the method described by Doares et al., (1991). Hydroxyl groups of the native EPS were first methylated as follows. About $2 \mathrm{mg}$ of EPS was dissolved in $500 \mu \mathrm{l}$ of DMSO and $500 \mu \mathrm{l}$ of Butyl Lithium was added $(2.5 \mathrm{M}$, in hexane, Sigma-Aldrich). Reaction was performed during $3 \mathrm{~h}$ at room temperature. Then, 500 $\mu l$ of iodomethane were added and the mixture was kept under agitation overnight. Methylation was stopped by addition of $1 \mathrm{ml}$ of ultrapure water and the exceeding methylation reagent was evaporated under nitrogen stream. The methylated EPS was extracted with $1 \mathrm{ml}$ of dichloromethane and centrifuged $(1 \mathrm{~min}, 1500 \mathrm{rpm})$. The organic phase was recovered, washed twice with $4 \mathrm{ml}$ of ultrapure water and evaporated under nitrogen stream. Methylated EPS was hydrolyzed with $500 \mu 1$ of trifluoroacetic acid ( $2 \mathrm{~N})$ and $20 \mu \mathrm{l}$ of myo-inositol was introduced $\left(1 \mathrm{mg} \cdot \mathrm{ml}^{-1}\right)$ as internal standard. The mixture was heated to 120 ${ }^{\circ} \mathrm{C}$ for $2 \mathrm{~h}$ and finally, acid was evaporated under nitrogen stream. EPS was reduced with $\mathrm{NaBD}_{4}$ at $80{ }^{\circ} \mathrm{C}$ during $30 \mathrm{~min}$. The excess of $\mathrm{NaBD}_{4}$ was eliminated with glacial $\mathrm{AcOH}$. Reducing agents were eliminated by 3 co-distillations with a methanol / acetic acid (9:1 ; v/v) mixture followed by 3 co-distillations with pure methanol. Finally, $O$-acetylation of the EPS was performed with $200 \mu \mathrm{l}$ of 1-methyl-imidazole and $2 \mathrm{ml}$ of $\mathrm{Ac}_{2} \mathrm{O}$ during $10 \mathrm{~min}$ at room temperature. $O$-acetylation was stopped by addition of $5 \mathrm{ml}$ of ultrapure water and the O-acetylated product was extracted twice with $1 \mathrm{ml}$ of dichloromethane. The organic phases were pooled and washed 5 times with $1 \mathrm{ml}$ of ultrapure water and evaporated under nitrogen stream.

\section{Results}

\subsection{EPS production}

Production of EPS was carried out in unbalanced $\mathrm{C} / \mathrm{N}$ culture medium. The maximum production of exopolysaccharide generally occurred at the end of the log phase. Two other carbon sources other than glucose were tested. Indeed, C. marina (DSMZ 4741) exhibits alginate lyase activity, suggesting macroalgae thalli as its natural environment. We chose to test 2 carbon sources related to macroalgae environment (alginic acid and mannitol). 3 carbon sources (glucose, mannitol and alginates) were added to the same culture medium to test different potential induction conditions: the average $\mathrm{L}_{6}$ EPS production rate was $0.4 \mathrm{~g} . \mathrm{l}^{-1}$ in a glucose induced medium, $0.3 \mathrm{~g} . \mathrm{l}^{-1}$ in a mannitol induced medium and $1 \mathrm{~g} . \mathrm{l}^{-1}$ in an alginate induced medium. Despite the better production rate obtained with alginic acid, glucose was 
chosen in order to avoid contamination by non-degraded alginic acid chains in the final product. For Cobetia marina, the maximum amount of EPS was obtained at $20{ }^{\circ} \mathrm{C}$, pH 7.6 after $50 \mathrm{~h}$ of culture. Over this time, the bacteria began to depolymerize its own EPS, the average molecular mass of $\mathrm{L}_{6}$ decreased (seen on size exclusion chromatography, data not shown) and seemed to synthesize PHA (according to inclusions observation by optic microscopy, data not shown). The consumption of glucose was about $17 \mathrm{~g} . \mathrm{l}^{-1}$ after $50 \mathrm{~h}$ of fermentation.

\subsection{EPS Characterization}

The purity of the purified EPS was estimated with colorimetric dosages. Total sugar content was measured by Dubois assay. Protein content was calculated by Bradford method and genetic material content was measured at $260 \mathrm{~nm}$. The lyophilized EPS is characterized by a high content of sugars $\left(78_{+/-6.1} \% \mathrm{w} / \mathrm{w}\right)$ and a low amount of proteins $\left(6_{+/-0.6} \% \mathrm{w} / \mathrm{w}\right)$ and genomic contaminants $\left(3_{+/-0.5} \% \mathrm{w} / \mathrm{w}\right)$.

The Fourier transform infrared spectroscopy was used as a preliminary analysis to assess the 'quality' of the sample before colorimetric dosages, osidic composition characterization and structural elucidation. It provides information about the purity of the polymer and helps to discriminate exopolysaccharides of protein or dna/rna made exopolymeric substances. This technique was also suitable to detect functional group as e.g. carboxylic function or sulfate ester function. The Fourier transform infrared spectroscopy (FTIR) performed on $\mathrm{L}_{6}$ shows a typical polysaccharide-fingerprint spectrum characterized by a broad band beyond $3000 \mathrm{~cm}^{-1}$, resulting from $\mathrm{O}-\mathrm{H}$ and $\mathrm{C}-\mathrm{H}$ stretching bands at $3420 \mathrm{~cm}^{-1}$ and $2900 \mathrm{~cm}^{-1}$ respectively, and an intense absorption band at $1600 \mathrm{~cm}^{-1}$ with a small shoulder around $1730 \mathrm{~cm}^{-1}$ due to the presence of carboxylic groups.

The $\mathrm{L}_{6}$ EPS was hydrolysed with TFA and the corresponding degradation products of $\mathrm{L}_{6}$ were analyzed by TLC. Sulphate and TBA staining were used to reveal total and unsaturated/deoxy sugars, respectively (Fig. 1.). The sulphate stainings indicated 2 prominent bands as well as faint bands in upper and lower positions of the two prominent bands, respectively. TBA staining indicated that the lower prominent band was unsaturated/deoxy sugar, while the upper prominent band showed no such sugar. Weak bands detected below the unsaturated/deoxy sugar correspond to incompletely hydrolyzed material comprising the unsaturated/deoxy sugar and other constituents. The trace band in the top of TBA-stained TLC may be another incompletely hydrolyzed material comprising of the unsaturated/deoxy 
sugar and of another constituent. These results indicate that repetitive unit of the $\mathrm{L}_{6} \mathrm{EPS}$ consists of at least 2 kinds of sugars which one is unsaturated/deoxy sugar.

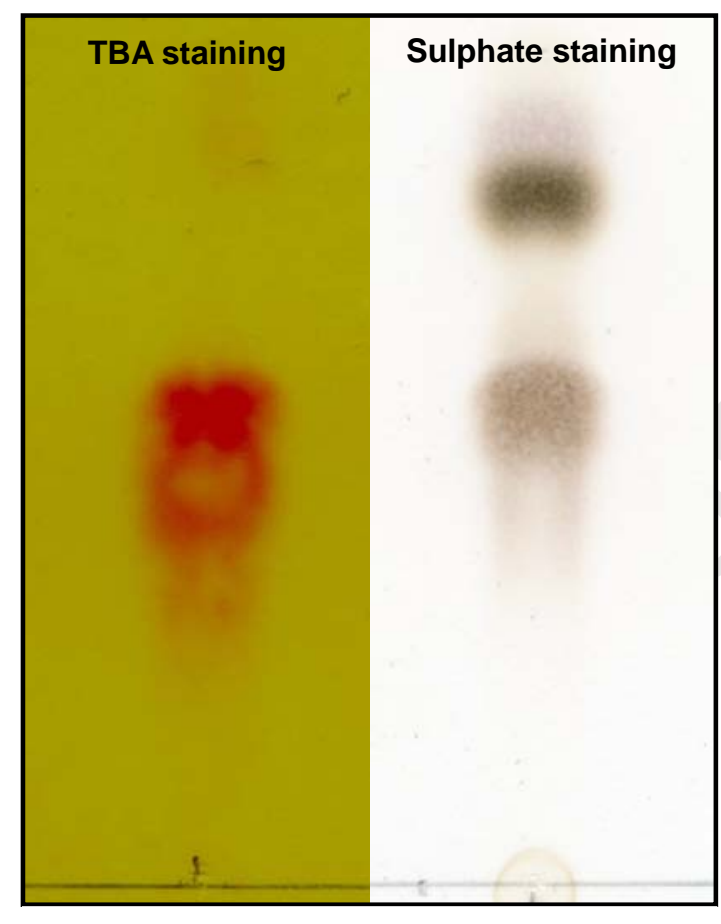

Fig. 1 : TBA and sulphate staining of $\mathrm{L}_{6}$ after TLC.

\subsection{Fractionation of the EPS}

$\mathrm{L}_{6}$ was fractionated on a DEAE column and eluted with $\mathrm{NaCl}$ gradient. The presence of polysaccharide in the different fractions was measured with Dubois assay. Only one peak was obtained corresponding to a $0.3 \mathrm{M}$ concentration of $\mathrm{NaCl}$ and suggesting a negatively charged polymer which is in accordance with the carboxylic groups observed with FTIR. The different fractions were analyzed with a native-polyacrylamide gel electrophoresis. The migration patterns showed an increase of the molecular weight during the peak elution suggesting an increase in the affinity toward DEAE resin with the increase in the chain length of EPS.

The $\mathrm{L}_{6}$ EPS is a high molecular weight polysaccharide with an average value of $2.7 .10^{5} \mathrm{Da}$ and a polydispersity index of about 3.75 , it represents some heterogeneous populations in terms of polysaccharide chains size.

\subsection{Chemical composition of $L_{6}$}


304 Alditol acetates of the $\mathrm{L}_{6}$ EPS were prepared and analyzed with gas chromatography and

305 ABEE labeled EPS by liquid chromatography. The ribose was the only residue that could

306

307

308

309

310

311

312

313

314

315

316

317

318

319

320

321

322

323

324

325

326

327

328

329

330

331

332

333 clearly be identified in both technics. Moreover, EPS substituents determination based on conductimetry using Dionex-HPLC after mild acidic degradation revealed the presence of pyruvate.

\subsection{Glycosidic linkage analysis}

A structural information about ribose linkage was obtained after analysis of the partially methylated alditols acetates of the $\mathrm{L}_{6}$ EPS . The presence of 1.2.4-tri-acetyl-1-deuterio-3.5-diO-methyl-D-ribitol was assessed by the observation of 2 majors signals at $\mathrm{m} / \mathrm{z} 161$ and $\mathrm{m} / \mathrm{z}$ 190, respectively. The $O$-acetylation of the $\mathrm{C} 2$ of the ribitol demonstrates the attachment of another glycosidic residue to the $\mathrm{C} 2$ of ribose under its native form and also determines the furanoid form of the ribose.

\subsection{NMR spectroscopy}

The ${ }^{1} \mathrm{H}$ and ${ }^{13} \mathrm{C}-\mathrm{NMR}$ study of $\mathrm{L}_{6}$ confirmed the high degree of purity of the exopolysaccharide and was in accordance with the presence of 2 osidic residues and one organic substituent. A total of 15 carbon peaks were observed on the ${ }^{13} \mathrm{C}-\mathrm{NMR}$ spectrum, and, from theses first data, EPS repetitive unit seems to be constituted by ribose (named spin system A) and KDO (3-deoxy-D-manno-oct-2-ulosonic acid, named spin-system B). The spin system-A shows a proton in the anomeric region $(5.3 \mathrm{ppm})$ that is characteristic of ribose (Kocharova et al., 1989). Its furanoid form and $\beta$ anomeric configuration was determined by the ${ }^{13} \mathrm{C}$ chemical shift of the C1 (107,1 ppm) and C4 (85 ppm) (Jennings et al., 1982 ; Van et al., 1983 ; Leone et al., 2007). The KDO residue was determined to be $\alpha$ based on the chemical shift difference between the axial and equatorial methylene proton signals $\left(\delta \mathrm{H}_{3}-\mathrm{H}_{3}{ }^{\prime}\right.$ $=0.52 \mathrm{ppm})$. The signal at $\delta 34.9 \mathrm{ppm}$ is characteristic of $\mathrm{C} 3$ of a $\mathrm{KDO} p$ and indicative of a pyranoid form (Lenter et al., 1990). The presence of pyruvate (spin system C) with an $\mathrm{R}$ configuration was also assessed by the chemical shift of the methyl protons (1.5 ppm) (Garreg et al., 1980). Integration of characteristic peaks (H1-A, H3-B, H3-C) suggests a Rib/KDO/Pyr 1:1:1 molar ratio (Fig. 2). All these data are strongly correlated with the data preliminary obtained by the chemical analysis (negative charge of the EPS, presence of carboxylic groups, two kinds of sugar constituents one of which is a deoxy sugar). 
334

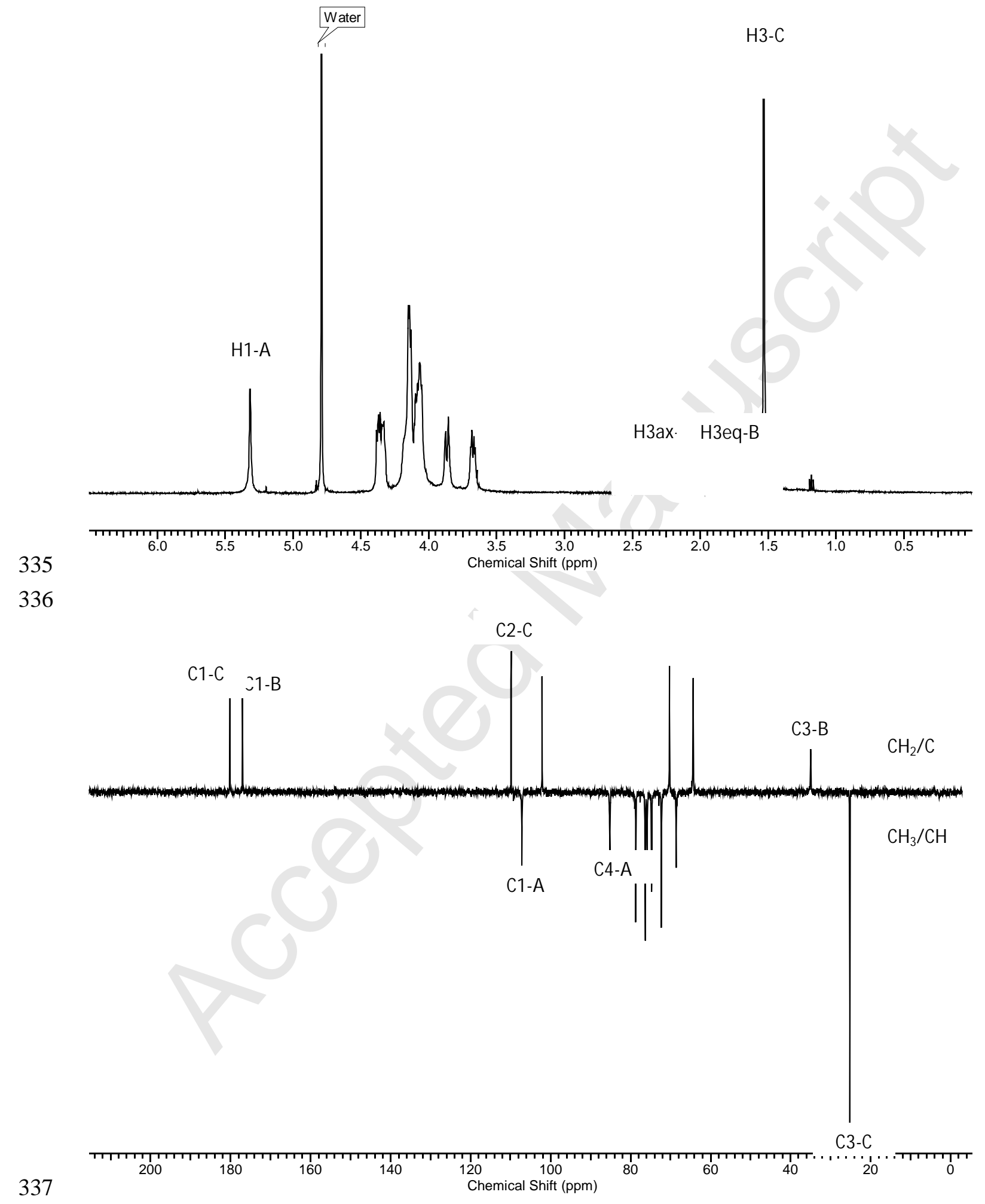

Fig. 2 : ${ }^{1} \mathrm{H}-\mathrm{NMR}$ and ${ }^{13} \mathrm{C}-\mathrm{NMR}$ (Jmod) spectra of $\mathrm{L}_{6}$. 
Additional data were provided by 2D NMR experiments. Assignment of each peaks are summarized in the Table 1. Accurate assignments of nucleus constituting the three spinsystems (A, B and C) were obtained by COSY and HMQC experiments (Fig. 4 ; Fig. 5 \& Table 1). Based on these results, the link between the spin-system A and B was determined by HMBC experiment (Fig. 6). Spectrum analysis showed a clear evidence for a $(1 \rightarrow 4)$ glycosidic linkage as proven by a strong correlation between the H1-A and the C4-B. This data was comforted by the downfield chemical shift of the C4-B compared with a similar polysaccharide from the literature (Lenter et al., 1990a). In addition, no correlation with the other potential link (C5-B/H1-A) was observable. The position of the pyruvate on the KDO was first established by the correlation between the $\mathrm{C} 2-\mathrm{C}$ and the H7-B/H8-B (Fig. 6). According to literature data, the important downfield chemical shift of the C7-B and C8-B (Table 1) suggested a substitution and, therefore, confirmed the second position between KDO and pyruvate (Jennings et al., 1982 ; Vann et al., 1983 ; Dengler et al., 1985 ; Lenter et $a l ., 1990)$. From all these data, the $\mathrm{L}_{6}$ EPS proves to be constituted by a sequence of $\rightarrow 2$ )- $\beta$-D$\operatorname{Rib} f-(1 \rightarrow 4)-[7,8-O-(\mathrm{Pyr})]-\alpha-\mathrm{D}-\mathrm{KDO} p-(2 \rightarrow$ (Fig. 3$)$.

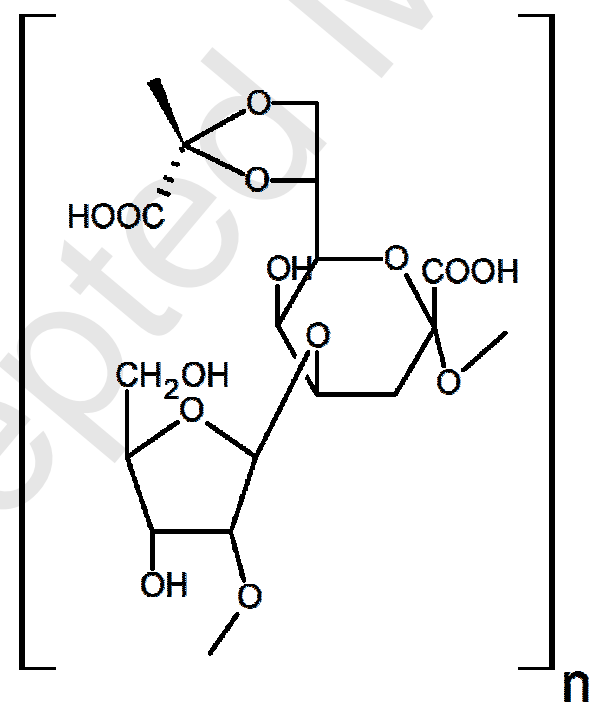

Fig. 3 : Chemical structure of repetitive unit of the EPS $L_{6}$

Table 1 : ${ }^{1} \mathrm{H}-\mathrm{NMR}$ and ${ }^{13} \mathrm{C}-\mathrm{NMR}$ spectral data for the $\mathrm{L}_{6}$ EPS.

\begin{tabular}{llllllllll} 
Residue & Nucleus & \multicolumn{10}{c}{ Chemical shift (ppm) } \\
\cline { 2 - 9 } & & 1 & 2 & 3 & 4 & 5 & 6 & 7 & 8 \\
\hline
\end{tabular}




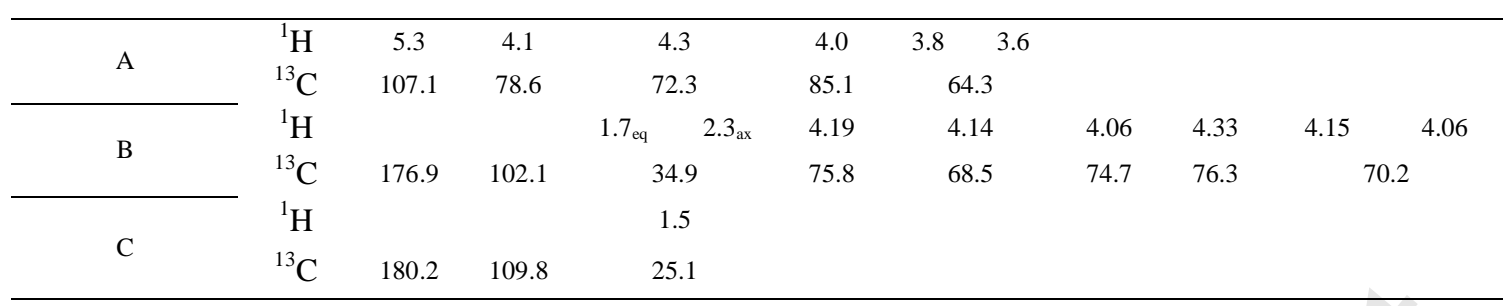

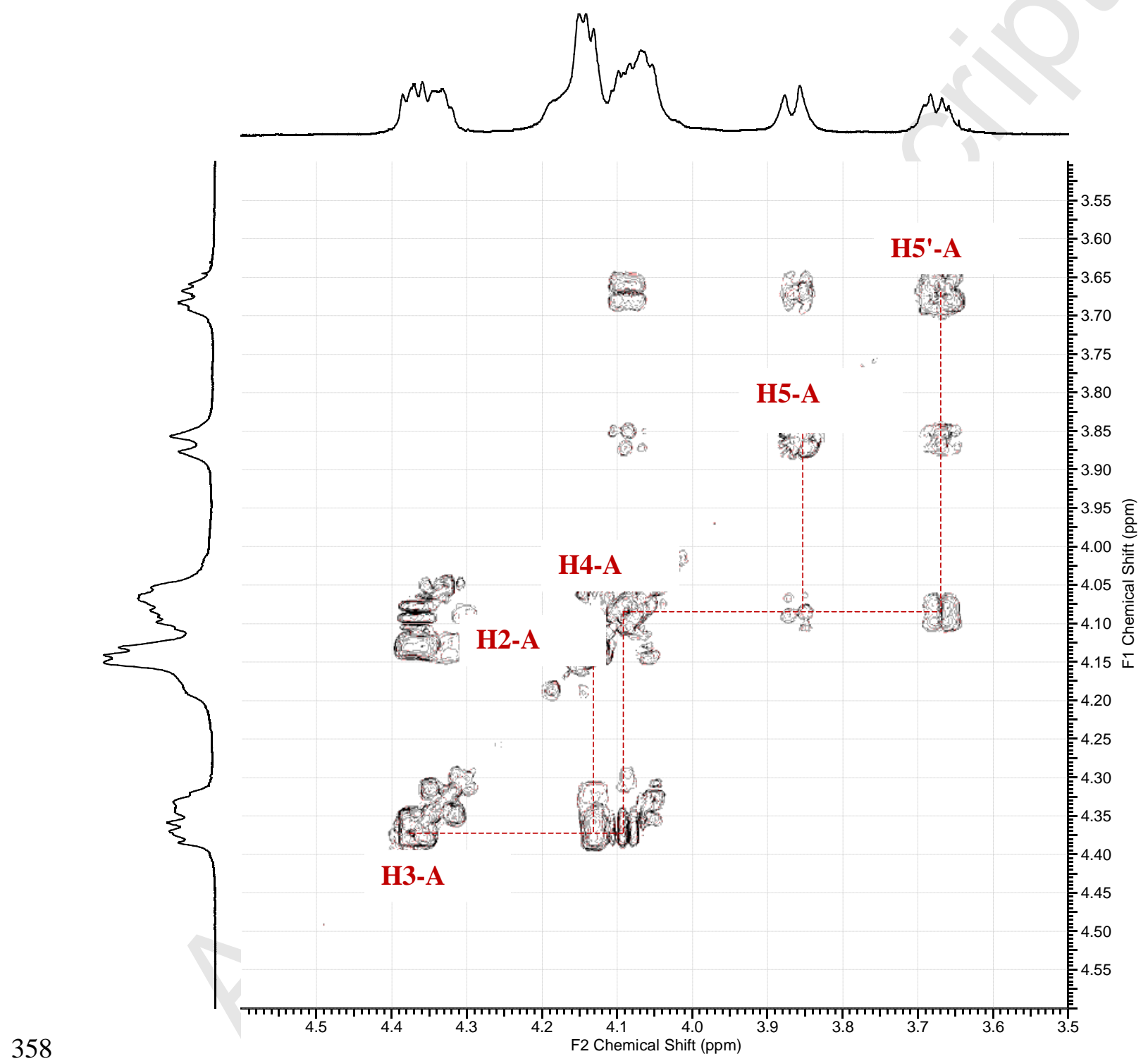

359

Fig. 4 : COSY spectrum of $\mathrm{L}_{6}$. 


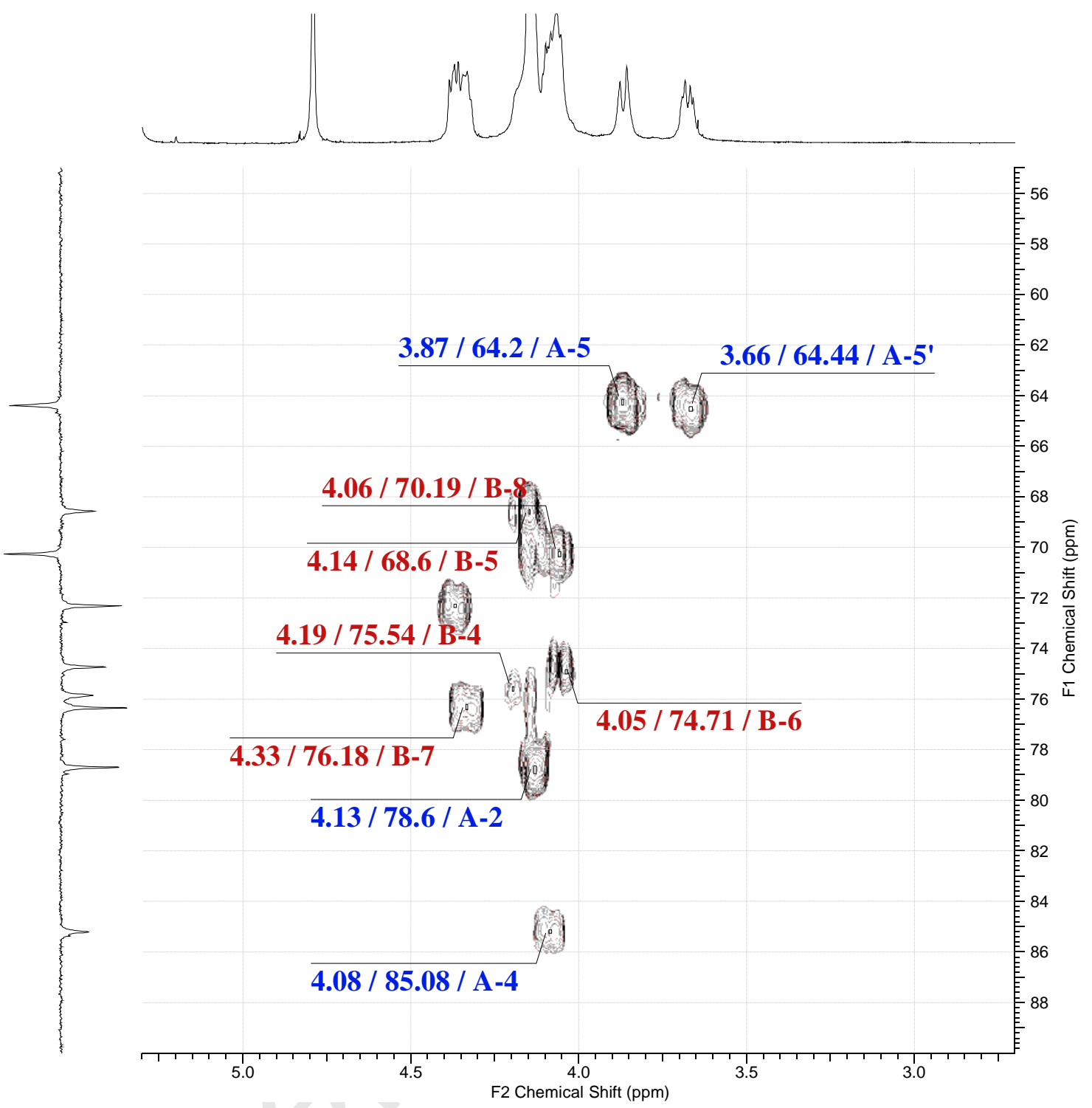

Fig. 5 : HMQC spectrum of $\mathrm{L}_{6}$ (Blue : Ribose, red : KDO). 


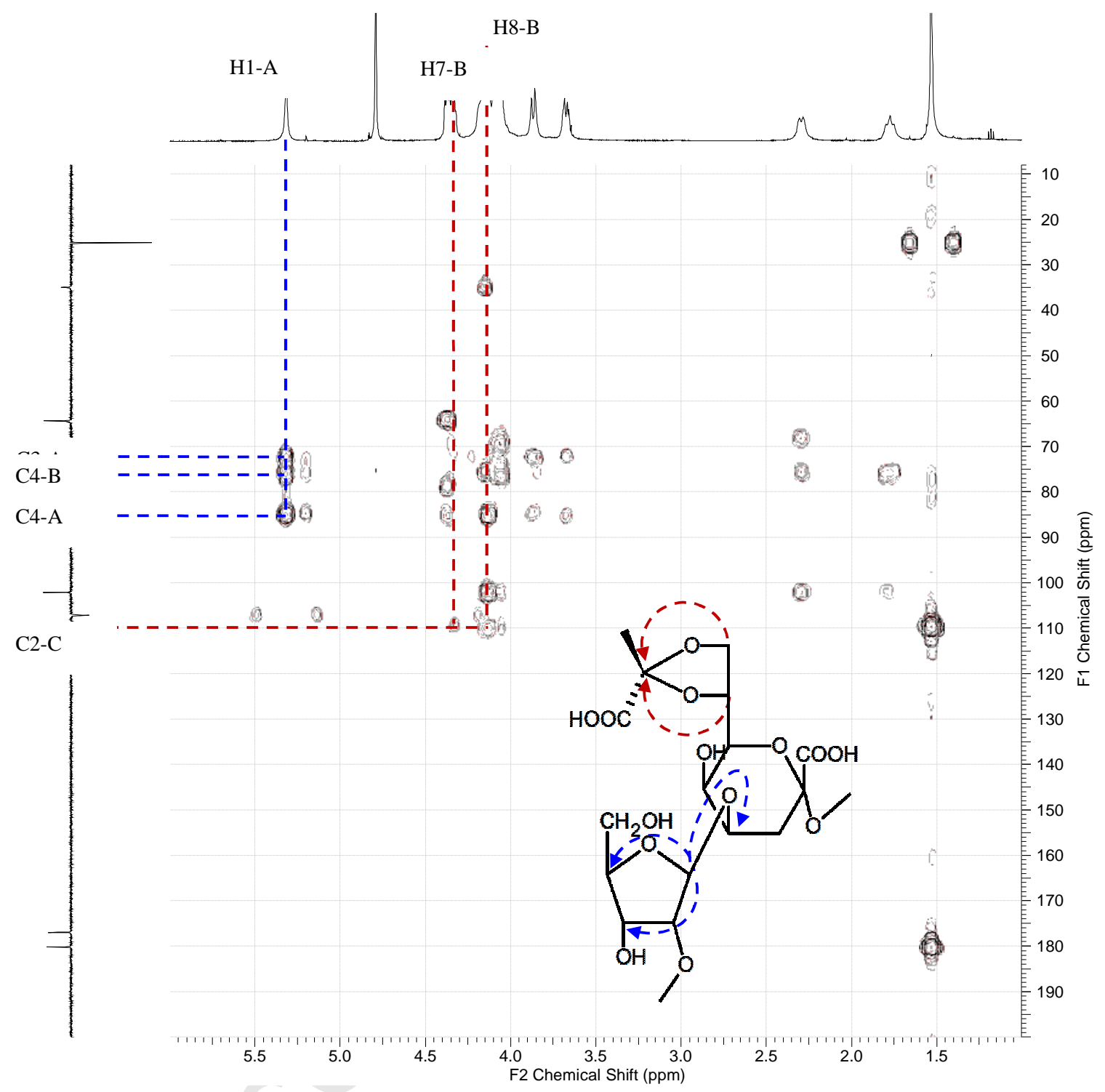

Fig. 6 : $\mathrm{HMBC}$ spectrum (partial contour plot) of $\mathrm{L}_{6}$.

\section{Discussion}

$\mathrm{L}_{6}$ is a soluble, non-viscous, non-branched acidic heteropolysaccharide of high molecular weight $(270 \mathrm{kDa})$ constituted of a repeating unit of $\rightarrow 2)-\beta$-D-Ribf-(1 $\rightarrow 4)$-[7,8-O-(Pyr)]- $\alpha$-D$\mathrm{KDO} p-\left(2 \rightarrow\right.$. In comparison with others marine bacterial EPS, $\mathrm{L}_{6}$ exhibits lowest polysaccharide chains sizes (Nichols et al., 2005 ; Satpute et al., 2010) . This is maybe due to the natural lability of the KDO residue which would be consistent with the important

373 polydispersity index measured in the study. Previous studies about the ability of Cobetia 374 marina to produce EPS do not match with present results (Shea et al., 1991 ; Kokoulin et al., 375 2014). Indeed, this polymer showed, in its composition and structure, strong analogies with 376 some Escherichia coli K-antigen polysaccharides from the group II (Table 2). K-antigens (for 
kepsular antigen) are a class of polysaccharides (LPS or free CPS) synthesized by pathogenic E. coli. They are separated in 2 major groups (I and II) and a minor one (III). The group II is characterized by its small molecular size (less than $50 \mathrm{kDa}$ ) and its acidic component (presence of ulosonic acid residues) (Jann et al., 1990). If KDO residues have already been reported in EPS (Nimtz et al., 1997 ; Steinmetz et al., 2000 ; Vanhaverbeke et al., 2001 ; Cescutti et al., 2003), its occurrence remains still rare in such type of polysaccharide. Most notably, this is the first time we described a 'true' EPS (understanding different from a LPS or capsular polysaccharide) from marine origin constituted by this type of chemical structure. . EPS $\mathrm{L}_{6}$ also exhibits other unique properties, e.g. the presence of a stoichiometric pyruvate in position 7 and 8 on the KDO residue, a high molecular weight compared to K-antigens and an important yield of production regarding previously described K-antigen producing strains. The 7,8-pyruvilated KDO is the more intriguing of these three features. This unusual case of substitution never reported before is maybe an adaptation to the ionic environment linked to the oceanic way of life of Cobetia marina DSMZ 4741. Another hypothesis could be a mechanism of resistance against phage-borne polysaccharidases. Indeed, viral KDOhydrolases generally act on non-substituted KDO residue (Sutherland, 1999, Labrie et al., 2010). This is even more surprising if we consider both the differences in terms of ecology and phylogeny between Cobetia marina and E. coli K-trains. Cobetia marina is a marine bacteria, often associated with marine algae (Kraiwatanapong et al., 1999 ; Ivanova et al., 2002 ; Ivanova et al., 2005). For example, the strain DSMZ 4741 exhibits an inducible alginate lyase and can produce $\mathrm{L}_{6}$ from the fermentation algae alginate, while the $\mathrm{K}$-strains of E. coli are always observed in human urinary tracts. Additionally, the K-strains of E. coli naturally synthesize a large amount of $\mathrm{K}$-antigen whereas $C$. marina requires the presence of a high concentration of carbohydrate substrate (glucose or alginic acid). Previous studies have shown that KDO-containing $\mathrm{K}$-antigen are susceptible to be hydrolyzed by phages borne polysaccharidases, allowing the implementation of enzybiotics (Altmann et al., 1987 ; Altmann et al., 1990 ; Nimmich, 1997). We also isolated, from seawater samples, bacteriophages able to depolymerize the EPS $\mathrm{L}_{6}$. The characterization of these phage enzymes is currently in progress (Lelchat et al., in prep). This study provides new evidences of the potential of marine plankton as a quasi-unexplored reservoir of novel bioactive compounds of medical or biotechnological interests.

\footnotetext{
Table 2 : Structural comparison between $\mathrm{L}_{6}$ and related Antigen-K (red : homologies with $\mathrm{L}_{6}$, green : structural
} singularity of $\mathrm{L}_{6}$ ). 


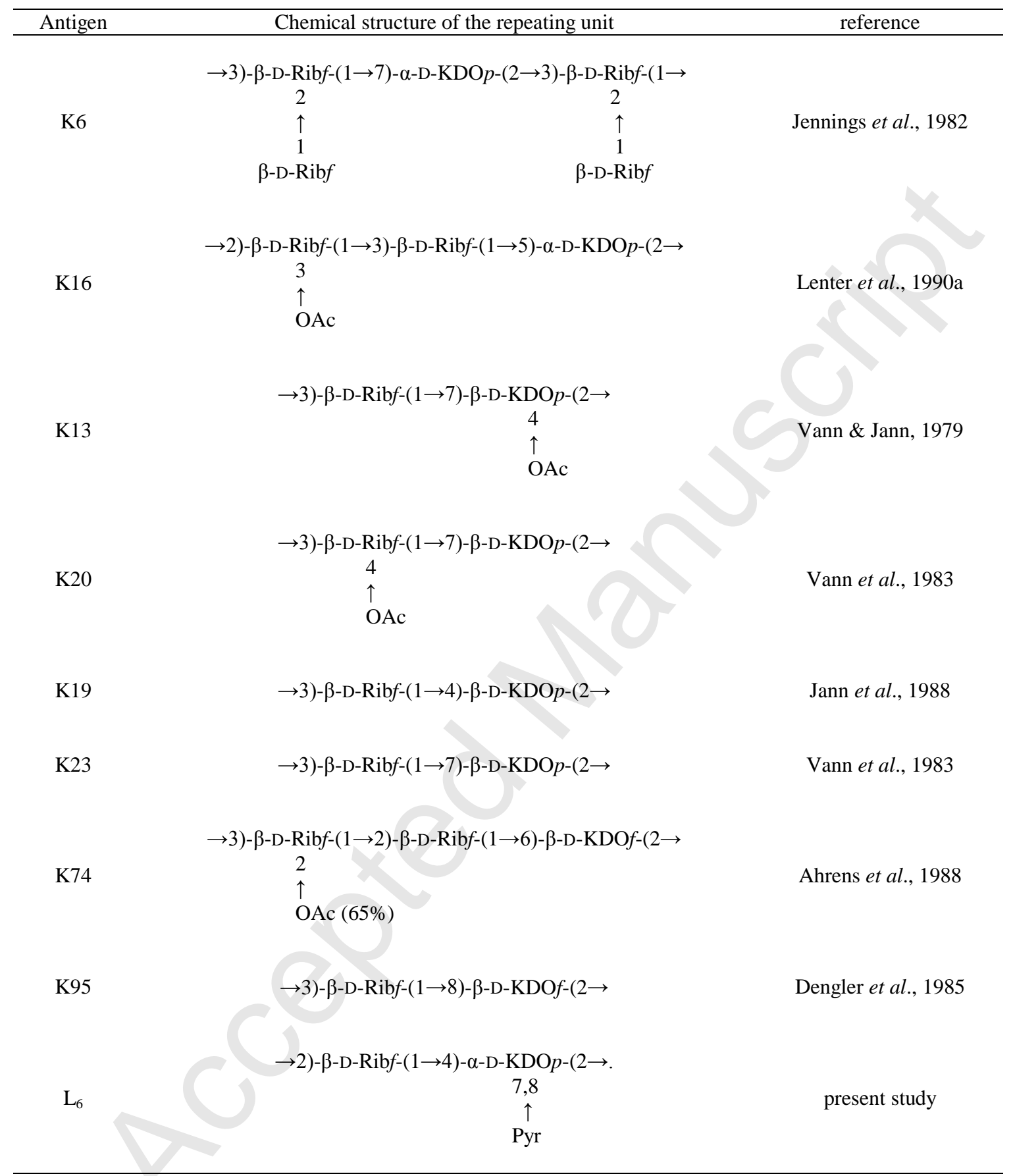

\section{Conclusion}

412 New molecules with antigenic properties are generally isolated from pathogenic organisms.

413 Here, we describe a new K-antigen-like EPS named $\mathrm{L}_{6}$ and synthesized by the non-pathogenic 414 marine bacterium Cobetia marina DSMZ 4741. This EPS exhibits an unusual and original 415 structure whose bioactivity potential is still to be studied. Additional works are currently 416 carried out in our lab with bacterioviruses infecting $C$. marina and able to depolymerize $\mathrm{L}_{6}$ 
417 with the aim of generate low molecular weight oligosaccharides consistent with biomedical

418 developments.

\section{Acknowledgments}

420 This research was financially supported by the Japan Society for the Promotion of Science, 421 the French Institute for Exploitation of the Sea and the Brittany Regional Council.

\section{References}

423 Ahrens, R., Jann, B., Jann, K., Brade, H., 1988. Structure of the K74 antigen from Escherichia 424 coli O44:K74:H18, a capsular polysaccharide containing furanosidic $\beta$-KDO residues.

425 Carbohydrate Research 179, 223-231. doi:10.1016/0008-6215(88)84120-X

426 Altmann, F., Christian, R., Czerny, T., Nimmich, W., März, L., 1990. Bacteriophage-

427 associated glycan hydrolases specific for Escherichia coli capsular serotype K12. European

428 Journal of Biochemistry 189, 307-312. doi:10.1111/j.1432-1033.1990.tb15491.x

429 Altmann, F., Kwiatkowski, B., Stirm, S., März, L., Unger, F.M., 1986. A bacteriophage-

430 associated glycanase cleaving $\beta$-pyranosidic linkages of 3-deoxy-D-manno-2-octulosonic acid

431 (KDO). Biochemical and Biophysical Research Communications 136, 329-335.

432 doi:10.1016/0006-291X(86)90914-9

433 Arahal, D.R., Castillo, A.M., Ludwig, W., Schleifer, K.H., Ventosa, A., 2002. Proposal of

434 Cobetia marina gen. nov., comb. nov., within the Family Halomonadaceae, to Include the

435 Species Halomonas marina. Systematic and Applied Microbiology 25, 207-211.

436 doi:10.1078/0723-2020-00113

437 Bradford, M.M., 1976. A rapid and sensitive method for the quantitation of microgram

438 quantities of protein utilizing the principle of protein-dye binding. Analytical Biochemistry

439 72, 248-254. doi:10.1016/0003-2697(76)90527-3

440 Cescutti, P., Scussolin, S., Herasimenka, Y., Impallomeni, G., Bicego, M., Rizzo, R., 2006.

441 First report of a lyase for cepacian, the polysaccharide produced by Burkholderia cepacia

442 complex bacteria. Biochemical and Biophysical Research Communications 339, 821-826.

443 doi:10.1016/j.bbrc.2005.11.104

444 Cobet, A.B., Jones, G.E., Albright, J., Simon, H., Wirsen, C., 1971. The Effect of Nickel on a

445 Marine Bacterium: Fine Structure of Arthrobacter marinus. J Gen Microbiol 66, 185-196.

446 doi:10.1099/00221287-66-2-185 
447 Dengler, T., Jann, B., Jann, K., 1985. Structure of the K95 antigen from Escherichia coli 448 O75:K95:H5, a capsular polysaccharide containing furanosidic KDO-residues. Carbohydrate 449 Research 142, 269-276. doi:10.1016/0008-6215(85)85028-X

450 DuBois, M., Gilles, K.A., Hamilton, J.K., Rebers, P.A., Smith, F., 1956. Colorimetric Method 451 for Determination of Sugars and Related Substances. Anal. Chem. 28, 350-356.

452 doi:10.1021/ac60111a017

453 Freitas, F., Alves, V.D., Reis, M.A.M., 2011. Advances in bacterial exopolysaccharides: from 454 production to biotechnological applications. Trends in Biotechnology 29, 388-398.

455 doi:10.1016/j.tibtech.2011.03.008

456 Garegg, P.J., Jansson, P.-E., Lindberg, B., Lindh, F., Lönngren, J., Kvarnström, I., Nimmich, 457 W., 1980. Configuration of the acetal carbon atom of pyruvic acid acetals in some bacterial 458 polysaccharides. Carbohydrate Research 78, 127-132. doi:10.1016/S0008-6215(00)83666-6

459 Hidalgo-Cantabrana, C., Sánchez, B., Milani, C., Ventura, M., Margolles, A., Ruas-Madiedo, 460 P., 2013. Exopolysaccharide biosynthesis in Bifidobacterium spp.: biological functions and a 461 genomic overview. Appl. Environ. Microbiol. AEM.02977-13. doi:10.1128/AEM.02977-13

462 Ivanova, E.P., Bakunina, I.Y., Sawabe, T., Hayashi, K., Alexeeva, Y.V., Zhukova, N.V., 463 Nicolau, D.V., Zvaygintseva, T.N., Mikhailov, V.V., 2002. Two Species of Culturable 464 Bacteria Associated With Degradation of Brown Algae Fucus Evanescens. Microb Ecol 43, 465 242-249. doi:10.1007/s00248-001-1011-y

466 Ivanova, E.P., Christen, R., Sawabe, T., Alexeeva, Y.V., Lysenko, A.M., Chelomin, V.P., 467 Mikhailov, V.V., 2005. Presence of Ecophysiologically Diverse Populations within Cobetia 468 marina Strains Isolated from Marine Invertebrate, Algae and the Environments. Microbes and 469 Environments 20, 200-207. doi:10.1264/jsme2.20.200

470 Jann, B., Ahrens, R., Dengler, T., Jann, K., 1988. Structure of the capsular polysaccharide 471 (K19 antigen) from uropathogenic Escherichia coli O25:K19:H12. Carbohydrate Research 472 177, 273-277. doi:10.1016/0008-6215(88)85064-X

473 Jann, B., Jann, K., 1990. Structure and Biosynthesis of the Capsular Antigens of Escherichia 474 coli, in: Jann, P.D.K., Jann, D.B. (Eds.), Bacterial Capsules, Current Topics in Microbiology 475 and Immunology. Springer Berlin Heidelberg, pp. 19-42. 
476

477

478

479

480

481

482

483

484

485

486

487

488

489

490

491

492

493

494

495

496

497

498

499

500

501

502

503

504

505

J. Jennings, H., Rosell, K.-G., G. Johnson, K., 1982. Structure of the 3-deoxy-d-mannooctulosonic acid-containing polysaccharide (K6 antigen) from escherichia coli LP 1092. Carbohydrate Research 105, 45-56. doi:10.1016/S0008-6215(00)81853-4

Kocharova, N.A., Hatano, K., Shaskov, A.S., Knirel, Y.A., Kochetkov, N.K., Pier, G.B., 1989. The structure and serologic distribution of an extracellular neutral polysaccharide from Pseudomonas aeruginosa immunotype 3. J. Biol. Chem. 264, 15569-15573.

Kokoulin, M.S., Kalinovsky, A.I., Komandrova, N.A., Tomshich, S.V., Romanenko, L.A., Vaskovsky, V.E., 2014. The sulfated O-specific polysaccharide from the marine bacterium Cobetia pacifica KMM 3879T. Carbohydrate Research 387, 4-9. doi:10.1016/j.carres.2014.01.015

Kraiwattanapong, J., Tsuruga, H., Ooi, T., Kinoshita, S., 1999. Cloning and sequencing of a Deleya marina gene encoding for alginate lyase. Biotechnology Letters 21, 169-174. doi:10.1023/A:1005435725903

Labrie, S.J., Samson, J.E., Moineau, S., 2010. Bacteriophage resistance mechanisms. Nat Rev Micro 8, 317-327. doi:10.1038/nrmicro2315

Lenter, M., Jann, B., Jann, K., 1990. Structure of the K16 antigen from escherichia coli O7:K16:H-, A Kdo-containing capsular polysaccharide. Carbohydrate Research 197, 197204. doi:10.1016/0008-6215(90)84142-H

Leone, S., Molinaro, A., Gerber, I.B., Dubery, I.A., Lanzetta, R., Parrilli, M., 2006. The Ochain structure from the LPS of the endophytic bacterium Burkholderia cepacia strain ASP B 2D. Carbohydrate Research 341, 2954-2958. doi:10.1016/j.carres.2006.10.010

Maréchal, J.-P., Culioli, G., Hellio, C., Thomas-Guyon, H., Callow, M.E., Clare, A.S., OrtaloMagné, A., 2004. Seasonal variation in antifouling activity of crude extracts of the brown alga Bifurcaria bifurcata (Cystoseiraceae) against cyprids of Balanus amphitrite and the marine bacteria Cobetia marina and Pseudoalteromonas haloplanktis. Journal of Experimental Marine Biology and Ecology 313, 47-62. doi:10.1016/j.jembe.2004.07.016

Nichols, C.A.M., Guezennec, J., Bowman, J.P., 2005. Bacterial Exopolysaccharides from Extreme Marine Environments with Special Consideration of the Southern Ocean, Sea Ice, and Deep-Sea Hydrothermal Vents: A Review. Mar Biotechnol 7, 253-271. doi:10.1007/s10126-004-5118-2 
506 Nimmich, W., 1997. Degradation studies on Escherichia coli capsular polysaccharides by

507 bacteriophages. FEMS Microbiology Letters 153, 105-110. doi:10.1111/j.1574-

$508 \quad$ 6968.1997.tb10470.x

509 Nimtz, M., Wray, V., Domke, T., Brenneke, B., Häussler, S., Steinmetz, I., 1997. Structure of 510 an Acidic Exopolysaccharide of Burkholderia pseudomallei. European Journal of

511 Biochemistry 250, 608-616. doi:10.1111/j.1432-1033.1997.0608a.x

512 Ophir, T., Gutnick, D.L., 1994. A Role for Exopolysaccharides in the Protection of

513 Microorganisms from Desiccation. Appl. Environ. Microbiol. 60, 740-745.

514 Ordax, M., Marco-Noales, E., López, M.M., Biosca, E.G., 2010. Exopolysaccharides favor

515 the survival of Erwinia amylovora under copper stress through different strategies. Research

516 in Microbiology 161, 549-555. doi:10.1016/j.resmic.2010.05.003

517 Poli, A., Anzelmo, G., Nicolaus, B., 2010. Bacterial Exopolysaccharides from Extreme

518 Marine Habitats: Production, Characterization and Biological Activities. Marine Drugs 8,

519 1779-1802. doi:10.3390/md8061779

520 Satpute, S.K., Banat, I.M., Dhakephalkar, P.K., Banpurkar, A.G., Chopade, B.A., 2010.

521 Biosurfactants, bioemulsifiers and exopolysaccharides from marine microorganisms.

522 Biotechnology Advances 28, 436-450. doi:10.1016/j.biotechadv.2010.02.006

523 Sen, R., 2008. Biotechnology in petroleum recovery: The microbial EOR. Progress in Energy

524 and Combustion Science 34, 714-724. doi:10.1016/j.pecs.2008.05.001

525 Shea, C., Nunley, J.W., Williamson, J.C., Smith-Somerville, H.E., 1991. Comparison of the

526 adhesion properties of Deleya marina and the exopolysaccharide-defective mutant strain

527 DMR. Appl. Environ. Microbiol. 57, 3107-3113.

528 Steinmetz, I., Nimtz, M., Wray, V., Häußler, S., Reganzerowski, A., Brenneke, B., 2000.

529 Exopolysaccharides of Burkholderia pseudomallei. Acta Tropica 74, 211-214.

530 doi:10.1016/S0001-706X(99)00072-8

531 Stewart, P.S., William Costerton, J., 2001. Antibiotic resistance of bacteria in biofilms. The

532 Lancet 358, 135-138. doi:10.1016/S0140-6736(01)05321-1

533 Suresh Kumar, A., Mody, K., Jha, B., 2007. Bacterial exopolysaccharides - a perception. J.

534 Basic Microbiol. 47, 103-117. doi:10.1002/jobm.200610203 
535 Sutherland, I.W., 1999. Polysaccharases for microbial exopolysaccharides. Carbohydrate

536 Polymers 38, 319-328. doi:10.1016/S0144-8617(98)00114-3

537 Sutherland, I.W., 2001. Biofilm exopolysaccharides: a strong and sticky framework.

538 Microbiology 147, 3-9.

539 Taylor, K.A., Buchanan-Smith, J.G., 1992. A colorimetric method for the quantitation of

540 uronic acids and a specific assay for galacturonic acid. Analytical Biochemistry 201, 190-

541 196. doi:10.1016/0003-2697(92)90194-C

542 Valepyn, E., Cabrera, J.C., Richel, A., Paquot, M., 2013. Water soluble exo-polysaccharide

543 from Syncephalastrum racemosum, a strong inducer of plant defence reactions. Carbohydrate

544 Polymers. doi:10.1016/j.carbpol.2013.10.018

545 Van der Merwe, P., Lannuzel, D., Nichols, C.A.M., Meiners, K., Heil, P., Norman, L.,

546 Thomas, D.N., Bowie, A.R., 2009. Biogeochemical observations during the winter-spring

547 transition in East Antarctic sea ice: Evidence of iron and exopolysaccharide controls. Marine

548 Chemistry 115, 163-175. doi:10.1016/j.marchem.2009.08.001

549 Vanhaverbeke, C., Heyraud, A., Achouak, W., Heulin, T., 2001. Structural analysis of the

550 exopolysaccharide from Burkholderia caribensis strain MWAP71. Carbohydrate Research

551 334, 127-133. doi:10.1016/S0008-6215(01)00176-8

552 Vanhooren, P., Vandamme, E.J., 1998. Biosynthesis, physiological role, use and fermentation

553 process characteristics of bacterial exopolysaccharides. Recent research developments in

554 fermentation \& bioengineering 253-300.

555 Vann, W.F., Jann, K., 1979. Structure and serological specificity of the K13-antigenic

556 polysaccharide (K13 antigen) of urinary tract-infective Escherichia coli. Infect. Immun. 25,

$557 \quad 85-92$.

558 Vann, W.F., Soderstrom, T., Egan, W., Tsui, F.P., Schneerson, R., Orskov, I., Orskov, F.,

559 1983. Serological, chemical, and structural analyses of the Escherichia coli cross-reactive

560 capsular polysaccharides K13, K20, and K23. Infect. Immun. 39, 623-629. 